\title{
INFORMATION AND INVESTOR BEHAVIOR SURROUNDING EARNINGS ANNOUNCEMENTS
}

\author{
García, C.J. ${ }^{(1)}$, Herrero, M.B. ${ }^{(1)(2)}$ e Ibáñez, A.M. ${ }^{(1)}$ \\ ${ }^{(1)}$ Departamento de Finanzas Empresariales, Universidad de Valencia \\ ${ }^{(2)}$ Departamento de Estudios de la Empresa, Universidad Católica de Valencia San Vicente Mártir
}

\section{PRELIMINARY VERSION}

\begin{abstract}
The goal of this paper is to analyze the impact of annual earnings announcements on the market through the order flow data in addition to the usual transaction data.

In this respect, examining order flow data can potentially reveal valuable information which is not available from transaction data. In fact, the data allow us to test hypotheses about asymmetric information and investor behavior and to test if the behavior varies with investor sophistication. In addition, the paper tries to identify the determinants of the impact on a firm's value using assumptions about investor behavior.
\end{abstract}

\section{1. - INTRODUCTION}

The aim of this paper is to study the information and investor behavior surrounding annual earnings releases in the Spanish Stock Market.

In recent research there has been growing interest regarding information asymmetries and investor behavior in stock markets. These topics have been analyzed around some events which affect companies' values. Since earnings announcements convey price relevant information and are routine and public, market participants will project their expectations about forthcoming announcements. 
In this sense, based on psychology literature which suggests that individuals are subject to cognitive and motivational errors, several behavioral finance models have suggested that investor reaction depends on the continuation of a series of similar earnings surprises.

Barberis, Shleifer and Vishny (1998) build on the psychology literature on heuristics, used to simplify decision-making and predictions. Because behavioral theories traders employ heuristic processes to estimate probabilities of future outcomes, individuals will underreact to new information (that is, information that disagrees with their views), but overreact when information is repeated (that is, information that agrees with their predictions). Daniel, Hirshleifer and Subrahmanyam (1998) propose a model based on two different behavioral biases, investor overconfidence (that is, overestimating one's ability to successfully perform a particular task) and biased selfattribution (that is, attributing successful outcomes to one's own skill but blaming unsuccessful outcomes on bad luck), which leads to similar behavior.

Moreover, regarding the reaction of investors to new information, we can also consider the possibility that investors make their trades on the basis of their probability estimation of future outcomes. With this in mind, this paper considers both investor anticipation and investor reaction.

From another perspective, the underlying psychology literature suggests that an investor's behavior should vary based on his or her level of sophistication (Shantikumar (2009) and Frieder (2008)). Therefore, a test of investor behavior should be controlled by the investor's sophistication level. More professional agents rely less on heuristics to make their investment decisions, and thus it will be the smaller traders who use heuristic predictions and who make mistakes that the professional agents do not make. Moreover, Barber and Odean (1996) use the attention day theory and argue that the smaller traders tend to be net purchasers of stocks on high attention days.

Lee (1992) is the first work that analyses the imbalances in order flow around the earnings announcement. Shantikumar (2009) compares the trading response of small traders and large traders to earnings surprises that occur during strings of either positive or negative surprises. She finds that small traders initiate more purchases (sales) in response to positive (negative) earnings surprises that occur later in a string than to 
similar surprises that occur earlier in the string. For larger traders, their activity in response to an earnings surprise is independent of the length of the string. Frieder (2004), in a similar way checks if traders deduce patterns in random sequences. She finds that the net buying by small investors increases with the number of consecutive positive earnings surprises. ${ }^{*}$

Accordingly, the main prediction is that individual traders will react more strongly to successive surprises than will sophisticated investors. Moreover, smaller traders will make their trading decisions on the basis of the previous series of similar earnings surprises, while the professional agent will trade on the basis of accurate information. Along these lines, Vieru et al (2006) find abnormal trading activity for sophisticated investors before earnings announcements and an opposite trading strategy after disclosure to all investors.

With respect to the information asymmetries in the stock market, if the market participant is informed, asymmetrical information should increase before earnings announcements (McNichols and Trueman (1994) and Demski and Feltman (1994)). On the other hand, if more public information leads to less private information gathering, an earnings announcement should be accompanied by a decrease in asymmetrical information. Moreover, if we take into account the existence of heterogeneity of information across investors caused by a differing ability to process the news or by the dispersal of opinion among investors, we find that information asymmetries are increased (Kim and Verrecchia (1994)).

Several studies detect an increase in information asymmetries around earnings announcements driven by the presence of informed agents that either have more information or have a superior ability to process it: Venkatesh and Chiang (1986), Lee et al. (1993), Brooks (1994), Krinsky and Lee (1996), Yohn (1998), Gajewski (1999) and Affleck-Graves et al. (2002) and Pronk (2004). By way of contrast, other studies such as Acker et al. (2002) and Otogawa (2003) detect a decrease in information asymmetries after the announcement, driven by the reduction of uncertainty when the earnings are announced.

\footnotetext{
* These papers differentiate between large and small traders as proxies for more and less sophisticated investors.
} 
In addition, some papers investigate the empirical relationship between information asymmetries around earnings disclosure and different variables such as the sign of the surprise or the firm size used as proxies for the quantity and quality of the information.

The relationship of the surprise sign with asymmetric information is not a closed question. Theoretically, Krishnan and Battacharya (1989) predict increases in information asymmetries following a positive surprise. On the other hand, Diamond and Verrecchia (1987) predict increases in information asymmetries following a negative surprise. In light of previous empirical results (see among others Patel (1993), Voetman (2000), Wael (2004)), fewer information asymmetries are expected around positive surprises than around negative ones due to greater uncertainty when announced earnings are less than the expected.

There seems to be more public information available about large firms than about small ones. Thus large firm earnings announcements may be incorporated into prices before the announcement, and more information asymmetry is expected around small firms. The results of Yohn (1998) are consistent with this argument while Patel (1993) finds no relationship between asymmetric information changes and firm size around earnings disclosure.

In order to fill in the analysis of annual earnings announcement, one interesting aspect to study will be to check the determinants impact on the price using assumptions about investor behavior. We examine if the response in asset prices is different for positive and negative surprises and if it depends on the magnitude of the surprise. Along these lines, Hayn (1995), Lipe et al. (1998), Acker (2002), and Garcia et al. (2009) for the Spanish market found different responses for bad and good news. With respect to the magnitude of the surprise, Abad et al (2004) for the Spanish market and Shantikumar (2009) for NYSE emphasize the importance of taking into account the size of the earnings variation.

Furthermore, we test whether the price change is different when a series of similar earnings surprises is reported. As we have mentioned above, the idea of different reactions to series has been used in behavioral finance papers such as Barberis et al. (1998) and Daniel et al. (1998). 
Finally, we examine whether information asymmetries measured by the PIN and the level of investor sophistication are determinants of abnormal returns. Consistent with Easley and O'Hara (1992) and Vega (2006), when sophisticated agents trade prior to earnings announcements, the stock return reaction would be smaller because private information would have already been incorporated into prices. Accordingly, we predict a negative relation between abnormal returns and the above mentioned variables.

The paper proceeds as follows. Section II describes the data and section III checks the main behavioral finance proposes. Section IV develops the information asymmetric analysis, section $\mathrm{V}$ analyses the determinants of price impact and, finally, section VI concludes.

\section{2. - DATA SETS}

Given our objective, we prepared a database consisting of the annual earnings announcements released by Spanish firms on the Spanish electronic stock market (hereinafter SIBE) for the period from 2001 to 2008. This data set was obtained from the Spanish Security Exchange Commission (CNMV) and includes the date of the announcement.

For an earnings announcement to be included in the final sample, we imposed several conditions:

- We have selected those firms listed in the SIBE for which stock market data was available in the period that comprises 125 days before the event day and 5 days after it.

- No other contaminating event must exist in the five days on either side of the event day that may affect firm price, such as dividend payments, equity issues or stock splits.

- We have selected those announcements for which annual earnings were available for the two years preceding the year of release.

These requirements reduced our sample considerably. The final number of earnings announcements included in the sample was 620 . 
Based on the amount of annual earnings, we have calculated the earnings per share (hereinafter EPS) in order to classify the announcement as either positive or negative news. Previous studies have shown the different market impacts of earnings announcements according to their favorable or unfavorable character. ${ }^{\dagger}$ We identify two types of announcements using the earning surprise measure: those in which actual earnings are higher than expected earnings (positive surprise) and those which are lower than expected (negative surprise). We have set expected earnings as the amount of earnings reached in the previous year. In our sample we distinguish 418 positive surprises and 202 negative surprises.

We use the earning surprise measure in order to establish the sequence of the surprise. When an earnings pattern of two previous positive (negative) surprises is observed we establish that there is a positive (negative) sequence that can lead the investor to believe that the firm will always produce positive (negative) earnings surprises.

Once the earnings were released, if the sign of the surprise was the same as in previous announcements, we establish that the sign has been confirmed. On the contrary, if the sign of the surprise was opposite to that in previous news, we establish that the sequence of earnings surprise has not been confirmed.

We have used market capitalization at the end of each year to split the sample into two groups depending on the size of the firms. As for the number of announcements, from 620 announcements, 377 belong to big firms and 243 to small firms.

Additionally, we have daily stock market data for all the firms that have been listed on SIBE. Specifically, this data set includes closing prices, dividends, capital increases and changes in nominal value, the number of transactions and volume (number of shares) traded. ${ }^{\ddagger}$

\footnotetext{
${ }^{\dagger}$ García et al. (2005) and (2006) prove the presence of positive (negative) abnormal returns around the release of good (bad) news.

* Splits have been taken into account in preparing the data time series.

$\S$ See, for example, Ball y Kothari (1991), Pope and Inyangete (1992), Opong (1995), Hew et al. (1996), Elsharkawy and Garrod (1996), Kallunki (1996), Booth et al. (1997), Laurent (2000), Odabassi (1998), Landsman and Maydew (2001) and Gajewski and Quéré (2001). Arcas and Rees (1999) Fernández and García (2001) and Sanabria (2005) investigate value generation around earnings announcements in the Spanish market.
} 
We have the SM and MP files of SIBE. The Spanish Stock Market is an order driven market. The SM files show the records that represent changes in the first level of the order book. The MP files contain the complete order book information.

From our database we have defined the following variables:

\section{$\underline{\text { Abnormal return: }}$}

We employ conventional event study methodology in order to compute abnormal returns $\left(A R_{i t}\right)$ at the announcement day $\mathrm{t}=0$.

$$
\mathrm{AR}_{\mathrm{it}}=\mathrm{R}_{\mathrm{it}}-\mathrm{E}\left(\mathrm{R}_{\mathrm{it}}\right)
$$

We estimate the expected returns following the standard Capital Asset Pricing Model (CAPM).* ${ }^{* \dagger \dagger}$

$$
\mathrm{E}\left(\mathrm{R}_{\mathrm{it}}\right)=\mathrm{R}_{\mathrm{ft}}-\beta_{\mathrm{i}}\left(\mathrm{R}_{\mathrm{Mt}}-\mathrm{R}_{\mathrm{ft}}\right)
$$

where $\mathrm{R}_{\mathrm{it}}$ is the simple daily return of the firm $i$ on day $t, \mathrm{R}_{\mathrm{ft}}$ is the daily return on Letras del Tesoro (Spanish Treasury Bill), ${ }^{\dagger} \mathrm{R}_{\mathrm{Mt}}$ is the daily return on a value-weighted market index (specifically the Madrid Stock Exchange Index -IGBM).

\section{Buy and sell orders:}

We have calculated for each firm and for each day of the window $\left(\mathrm{t}_{0-30}, \mathrm{t}_{0+30}\right)$ the variables Buy ${ }_{i t}$ and Sell ${ }_{\text {it }}$ defined as the euro value of buy orders and euro value of sell orders of firm $i$ on day $t$, respectively. For this purpose, we have employed our dataset which contains daily information about all orders executed and not executed in the SIBE -volume, price and time-. These data allow us to classify the buy and sell orders without using algorithms such as the one proposed by Lee and Ready (1991).

\footnotetext{
${ }^{* *}$ In order to ensure the robustness of our results to model specification we also estimate expected returns following the three-factor model developed by Fama and French (1993). Fama and French results are not presented because there are no differences with the CAPM model.

${ }^{++}$The estimation-window is defined to be a one-hundred-day window $\left(\mathrm{t}_{0-25}, \mathrm{t}_{0-125}\right)$.

${ }^{*}$ Treasury bill information has been obtained from the Bank of Spain.
} 


\section{3. - TRADER REACTIONS TO EARNINGS SURPRISE.}

The primary variable of interest to check the main behavioral finance proposes is the trade imbalance. If every trade after an announcement were being initiated by the buy side, then the trading reaction to that announcement would be extremely positive. Similarly, if all trades were being initiated by the sell side, then the reaction would be strongly negative.

To capture this concept, we have calculated for each earning announcement $(t)$ the trade imbalance (TI) for each firm $(i)$ for each of the thirty days $(d)$ around the day of announcement as follows:

$$
\mathrm{TI}_{\mathrm{i}, \mathrm{d}}^{\mathrm{t}}=\frac{\text { Buys }_{\mathrm{it}}-\text { Sells }_{\mathrm{it}}}{\text { Buys }_{\mathrm{it}}+\text { Sells }_{\mathrm{it}}} * 100
$$

We have calculated the average trade imbalance $\left(\mathrm{TI}_{\mathrm{i}, \mathrm{KL}}^{\mathrm{t}}\right)$ into five days intervals where $\mathrm{K}$ and $\mathrm{L}$ refer to the beginning and end, respectively, of the intervals analyzed.

Our data do not enable us to identify the investors and observe their strategies. Based on theoretical and empirical evidence that small trades are generally made by individuals (unsophisticated investors) and large trades by professional institutional investors (sophisticated investors) we use trade size as a proxy for investor sophistication (see Lee (1992), Shanthinkumar (2004), Frieder (2004), Chiang y Wang (2007), among others)..$^{\S}$

In order to take into account investor sophistication, we use the next trade size cutoff. We sort all executed orders in euros by year and firm and make ten categories (percentile one contains the smallest orders and percentile ten contains the largest ones). We use the first, second and third percentile cutoffs for unsophisticated investors and the eighth, ninth and tenth percentile cutoffs for sophisticated investors and the rest of the orders are eliminated.

\footnotetext{
$\S \S$ Previous evidence such as Chen and Lakonishok (1991) shows that only 10\% of institutional investors carry out transactions of less than $\$ 10,000$.
} 
We are interested in testing whether sophisticated and/or unsophisticated investors have the ability to predict the consequences of earnings announcements. Therefore, we examine for all firms the order imbalance in some intervals around the announcement.

Before the earnings announcements we check the possibility that investors decide on their trades based on their probability estimation of the future outcome, taking into account that smaller investors rely on simple heuristics to value the firms and larger traders rely on well-defined valuation models.

In order to evaluate the investor anticipation by trading reaction, we estimate the following model:

$$
\mathrm{TI}_{\mathrm{i}, \mathrm{KL}}^{\mathrm{t}}=\propto+\beta_{1} \mathrm{PE}_{\mathrm{i}}+\beta_{2} \mathrm{NE}_{\mathrm{i}}+\beta_{3} \mathrm{PS}_{\mathrm{i}}+\varepsilon_{\mathrm{i}}
$$

where PE is a dummy variable which equals 1 for positive sequences and zero otherwise, NE is a dummy variable which equals 1 for negative sequences and zero otherwise and PS is a dummy variable which equals 1 for positive surprises and zero otherwise.

Once the earnings announcement has been released, we check if the behavior of unsophisticated investors confirms the overreaction and the self-attribution provided in the previous literature. To evaluate this hypothesis we estimate the following models:

$$
\begin{gathered}
\mathrm{TI}_{\mathrm{i}, \mathrm{KL}}^{\mathrm{t}}=\propto_{P}+\lambda_{1} \mathrm{CPS}_{\mathrm{i}}+\lambda_{3} \mathrm{UPS}_{\mathrm{i}}+\mu_{\mathrm{i}} \\
\mathrm{TI}_{\mathrm{i}, \mathrm{KL}}^{\mathrm{t}}=\propto_{N}+\lambda_{2} \mathrm{CNS}_{\mathrm{i}}+\lambda_{4} \mathrm{UNS}_{\mathrm{i}}+\omega_{\mathrm{i}}
\end{gathered}
$$

where CPS is a dummy variable which equals 1 for confirmed positive surprises and zero otherwise, CNS is a dummy variable which equals 1 for confirmed negative surprises and zero otherwise, UPS is a dummy variable which equals 1 for unconfirmed positive surprises and zero otherwise and UNS is a dummy variable which equals 1 for unconfirmed negative surprises and zero otherwise.

Since the quality and quantity of information is higher in large firms than in small ones -Atiase (1985) and Dempsey (1989) among others- we conduct the analysis for the full sample and by company size categories. 
Table 1 shows the results for the full sample. In the pre-announcement period we note an important difference between sophisticated and unsophisticated investors before the earnings announcement. The results show that unsophisticated investors are unable to predict the sign of the news. Only when the past announcements were positive surprises do they show a different and statistically significant behavior immediately before the announcement (five days before the release). This results support the heuristic behavior of unsophisticated investors.

\section{TABLE 1}

\section{ANTICIPATION BY TRADING REACTION (ALL FIRMS)}

In order to evaluate the investor anticipation by trading reaction we estimate the following model (pre-announcement period):

$$
\mathrm{TI}_{\mathrm{i}, \mathrm{KL}}^{\mathrm{t}}=\alpha+\beta_{1} \mathrm{PE}_{\mathrm{i}}+\beta_{2} \mathrm{NE}_{\mathrm{i}}+\beta_{3} \mathrm{PS}_{\mathrm{i}}+\varepsilon_{\mathrm{i}}
$$

where $\mathrm{PE}$ is a dummy variable for positive sequences, $\mathrm{NE}$ is a dummy variable for negative sequences and PS is a dummy variable for positive surprises

PANEL A: ALL FIRMS

\begin{tabular}{|c|c|c|c|c|c|c|c|c|c|c|c|}
\hline \multicolumn{9}{|c|}{ UNSOPHISTICATED INVESTORS } \\
\hline
\end{tabular}

PANEL B: LARGE FIRMS

\begin{tabular}{|c|c|c|c|c|c|c|c|c|c|c|c|c|}
\hline & \multicolumn{6}{|c|}{ UNSOPHISTICATED INVESTORS } & \multicolumn{6}{|c|}{ SOPHISTICATED INVESTORS } \\
\hline & {$[-30,-26]$} & {$[-25,-21]$} & {$[-20,-16]$} & {$[-15,-11]$} & {$[-10,-6]$} & {$[-5,-1]$} & $\begin{array}{c}-30,- \\
26]\end{array}$ & $\begin{array}{c}{[-25,-} \\
21]\end{array}$ & $\begin{array}{c}-20,- \\
16]\end{array}$ & $\begin{array}{c}{[-15,-} \\
11]\end{array}$ & {$[-10,-6]$} & {$[-5,-1]$} \\
\hline$\alpha$ & $\begin{array}{l}-6,87 \% \\
(0,0973)\end{array}$ & $\begin{array}{c}-7,00 \% \\
(0,0509)\end{array}$ & $\begin{array}{c}-5,09 \% \\
(0,2214)\end{array}$ & $\begin{array}{l}-8,75 \% \\
(0,0197)\end{array}$ & $\begin{array}{c}-4,44 \% \\
(0,3254)\end{array}$ & \begin{tabular}{|l|}
$-10,01 \%$ \\
$(0,0115)$
\end{tabular} & $\begin{array}{c}0,21 \% \\
(0,9445)\end{array}$ & $\begin{array}{c}-1,95 \% \\
(0,5230)\end{array}$ & $\begin{array}{c}-1,76 \% \\
(0,5073)\end{array}$ & $\begin{array}{c}2,09 \% \\
(0,4575)\end{array}$ & $\begin{array}{c}0,79 \% \\
(0,7223)\end{array}$ & $-4,85 \%$ \\
\hline$\beta_{1}$ & $\begin{array}{c}1,95 \% \\
(0,6273 \\
\end{array}$ & $\begin{array}{c}-0,22 \% \\
(0,9482)\end{array}$ & $\begin{array}{l}-3,01 \% \\
(0,3902)\end{array}$ & $\begin{array}{c}-1,42 \% \\
(0,6732)\end{array}$ & $\begin{array}{c}2,66 \% \\
(0,4743)\end{array}$ & $\begin{array}{c}7,60 \% \\
(0,0274) \\
\end{array}$ & $\begin{array}{c}-0,42 \% \\
(0,8862) \\
\end{array}$ & $\begin{array}{c}3,00 \% \\
(0,3098)\end{array}$ & $\begin{array}{c}4,06 \% \\
(0,1210)\end{array}$ & $\begin{array}{c}-1,92 \% \\
(0,4804)\end{array}$ & $\begin{array}{c}0,44 \% \\
(0,8271) \\
\end{array}$ & $\begin{array}{c}0,34 \% \\
(0,8851)\end{array}$ \\
\hline$\beta_{2}$ & $\begin{array}{l}-0,36 \% \\
0,9541\end{array}$ & $\begin{array}{c}-3,60 \% \\
(0,5727)\end{array}$ & $\begin{array}{c}-5,95 \% \\
(0,3248)\end{array}$ & $\begin{array}{c}-6,77 \% \\
(0,3007)\end{array}$ & $\begin{array}{c}-5,60 \% \\
(0.3249)\end{array}$ & $\begin{array}{c}9,13 \% \\
(0,1231)\end{array}$ & $\begin{array}{c}-3,97 \% \\
(0,3877)\end{array}$ & $\begin{array}{c}1,38 \% \\
(0,7136)\end{array}$ & $\begin{array}{c}-0,31 \% \\
(0,9520)\end{array}$ & $\begin{array}{c}-4,27 \% \\
(0,2538)\end{array}$ & $\begin{array}{c}-4,21 \% \\
(0,3199)\end{array}$ & $\begin{array}{c}-1,10 \% \\
(0,8284)\end{array}$ \\
\hline$\beta_{3}$ & $\begin{array}{l}-0,85 \% \\
(0,7529 \\
\end{array}$ & $\begin{array}{c}-0,58 \% \\
(0,8290) \\
\end{array}$ & $\begin{array}{c}1,04 \% \\
(0,7364)\end{array}$ & $\begin{array}{c}1,79 \% \\
(0,5124) \\
\end{array}$ & $\begin{array}{c}-2,41 \% \\
(0,4386)\end{array}$ & \begin{tabular}{|c|}
$-2,18 \%$ \\
$(0,4451)$ \\
\end{tabular} & $\begin{array}{c}2,40 \% \\
(0,2810)\end{array}$ & $\begin{array}{c}4,37 \% \\
(0,0422) \\
\end{array}$ & $\begin{array}{c}2,67 \% \\
(0,2176) \\
\end{array}$ & $\begin{array}{c}1,61 \% \\
(0,4051)\end{array}$ & $\begin{array}{c}4,56 \% \\
(0,025) \\
\end{array}$ & $\begin{array}{c}6,56 \% \\
(0,0005) \\
\end{array}$ \\
\hline
\end{tabular}

PANEL C: SMALL FIRMS

\begin{tabular}{|c|c|c|c|c|c|c|c|c|c|c|c|c|}
\hline & \multicolumn{6}{|c|}{ UNSOPHISTICATED INVESTORS } & \multicolumn{6}{|c|}{ SOPHISTICATED INVESTORS } \\
\hline & {$[-30,-26]$} & {$[-25,-21]$} & {$[-20,-16]$} & {$[-15,-11]$} & {$[-10,-6]$} & {$[-5,-1]$} & $\begin{array}{c}{[-30,-} \\
26]\end{array}$ & {$[-25,-21]$} & {$[-20,-16]$} & {$[-15,-11]$} & {$[-10,-6]$} & {$[-5,-1]$} \\
\hline & $\begin{array}{l}-3,49 \% \\
(0,4493)\end{array}$ & $\begin{array}{c}-9,52 \% \\
(0,1020)\end{array}$ & $\begin{array}{r}-11,97 \% \\
(0,0039)\end{array}$ & $\begin{array}{c}-4,14 \% \\
(0,3337)\end{array}$ & $\begin{array}{c}-5,16 \% \\
(0,1825)\end{array}$ & $\begin{array}{l}-15,37 \% \\
(0,0006) \\
\end{array}$ & $\begin{array}{c}2,80 \% \\
(0,4513)\end{array}$ & $\begin{array}{c}2,11 \% \\
(0,6259)\end{array}$ & $\begin{array}{c}4,65 \% \\
(0.3057)\end{array}$ & $\begin{array}{c}6,13 \% \\
(0,1083)\end{array}$ & $\begin{array}{c}2,03 \% \\
(0,5590) \\
\end{array}$ & $\begin{array}{c}-8,56 \% \\
(0,0396) \\
\end{array}$ \\
\hline & $\begin{array}{c}1,22 \% \\
(0,7970)\end{array}$ & $\begin{array}{c}3,55 \% \\
(0,5176)\end{array}$ & $\begin{array}{c}8,46 \% \\
(0,0476)\end{array}$ & $\begin{array}{c}3,75 \% \\
(0,3937)\end{array}$ & $\begin{array}{c}3,23 \% \\
(0,4182)\end{array}$ & $\begin{array}{r}11,19 \% \\
(0,0152) \\
\end{array}$ & $\begin{array}{c}0,70 \% \\
(0,8700)\end{array}$ & $\begin{array}{c}-2,22 \% \\
(0,5898)\end{array}$ & $\begin{array}{c}-4,10 \% \\
(0.3519)\end{array}$ & $\begin{array}{c}-4,94 \% \\
(0.2551)\end{array}$ & \begin{tabular}{|c|}
$-4,04 \%$ \\
$(0,2765)$ \\
\end{tabular} & $\begin{array}{c}7,49 \% \\
(0,0785)\end{array}$ \\
\hline & $\begin{array}{c}1,32 \% \\
(0,8181)\end{array}$ & $\begin{array}{c}3,48 \% \\
(0,6041) \\
\end{array}$ & $\begin{array}{c}7,88 \% \\
(0,1666) \\
\end{array}$ & $\begin{array}{c}-6,75 \% \\
(0,2232)\end{array}$ & $\begin{array}{c}0,98 \% \\
(0,8602)\end{array}$ & $\begin{array}{c}7,07 \% \\
(0,2128) \\
\end{array}$ & $\begin{array}{c}-0,56 \% \\
(0,9160) \\
\end{array}$ & $\begin{array}{c}5,23 \% \\
(0.3059) \\
\end{array}$ & $\begin{array}{c}-6,48 \% \\
(0,2706)\end{array}$ & $\begin{array}{c}1,67 \% \\
(0,7633) \\
\end{array}$ & \begin{tabular}{|c|}
$2,24 \%$ \\
$(0,6241)$ \\
\end{tabular} & $\begin{array}{c}9,77 \% \\
(0,1202) \\
\end{array}$ \\
\hline & $\begin{array}{c}0,01 \% \\
(0,9984)\end{array}$ & $\begin{array}{c}2,76 \% \\
(0,5052)\end{array}$ & $\begin{array}{c}4,85 \% \\
(0,2069)\end{array}$ & $\begin{array}{c}1,88 \% \\
(0,6239)\end{array}$ & $\begin{array}{c}2,81 \% \\
(0,4424)\end{array}$ & $\begin{array}{c}1,50 \% \\
(0,7029)\end{array}$ & $\begin{array}{c}-0,65 \% \\
(0,8457)\end{array}$ & $\begin{array}{c}4,36 \% \\
(0.1695)\end{array}$ & $\begin{array}{c}4,49 \% \\
(0,1972)\end{array}$ & $\begin{array}{c}3,62 \% \\
(0,3098)\end{array}$ & $\begin{array}{c}3,41 \% \\
(0,2779)\end{array}$ & $\begin{array}{c}-1,42 \% \\
(0,6809)\end{array}$ \\
\hline
\end{tabular}

This last result is also observed for sophisticated investors immediately before the announcement. Additionally, sophisticated investors have the capacity to predict the 
sign of the earning release. For positive surprises they show a statistically significant behavior from 25 days before the announcement.

Although the results are not presented, we have repeated the analysis presented in Table 1 changing the variable positive surprise (PS) with a dummy variable which equals 1 for negative surprise (NS) and zero otherwise. This variable is statistically significant just in the interval immediately prior to the announcement and for sophisticated investors.

This confirms that, in contrast to unsophisticated investors, sophisticated investors either have private information or a greater ability to search for and interpret news. The evidence suggests that unsophisticated investors have less ability to find and interpret information resources and they decide based on the historical sequence.

In the pre-announcement period we see, in large firms, the same results commented on previously for the full sample.

Nevertheless, for small firms we do not find differences between sophisticated and unsophisticated investors. In both cases we observe buy trades imbalances for firms which have a good expectation, that is to say, a previous positive sequence. A possible explanation could be the lack of information about small companies and/or the lack of interest of sophisticated investors in them. In fact, some papers (Callen et al. (2005)) provide evidence that sophisticated investors have difficulty in processing financial information for some firms.

In the post announcement period (the results are in Table 2 and 3) we observe that unsophisticated investors show negative trading imbalances. This result is observed in all cases, that is, for positive and negative surprises and in large and small firms.

\footnotetext{
*** We find for sophisticated investors and for the nearest interval to the announcements a statistically significant coefficient $(-3,6 \%)$.
} 


\section{TABLE 2}

\section{GOOD EARNING RELEASE AND TRADING REACTION}

Once the earnings announcement has been released, we check if the behavior of unsophisticated investors confirms the overreaction and the self-attribution provided in the previous literature. To evaluate this hypothesis we estimate the following models:

$$
\mathrm{TI}_{\mathrm{i}, \mathrm{KL}}^{\mathrm{t}}=\alpha_{\mathrm{P}}+\lambda_{1} \mathrm{CPS}_{\mathrm{i}}+\lambda_{3} \mathrm{UPS}_{\mathrm{i}}+\mu_{\mathrm{i}}
$$

where CPS is a dummy variable which equals 1 for confirmed positive surprises and zero otherwise and UPS is a dummy variable which equals 1 for unconfirmed positive surprises and zero otherwise.

PANEL A: ALL FIRMS

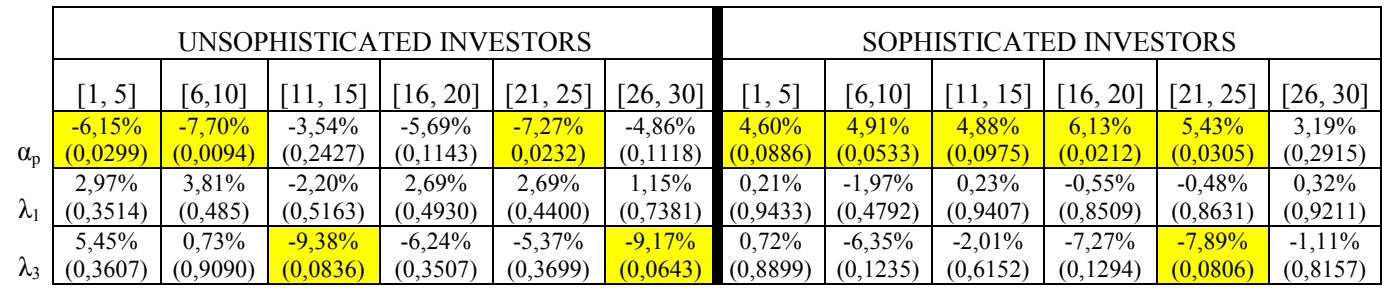

PANEL B: LARGE FIRMS

\begin{tabular}{|c|c|c|c|c|c|c|c|c|c|c|c|}
\hline \multicolumn{6}{|c|}{ UNSOPHISTICATED INVESTORS } & \multicolumn{6}{|c|}{ SOPHISTICATED INVESTORS } \\
\hline$[1,5]$ & {$[6,10]$} & {$[11,15]$} & {$[16,20]$} & {$[21,25]$} & {$[26,30]$} & {$[1,5]$} & {$[6,10]$} & {$[11,15]$} & {$[16,20]$} & {$[21,25]$} & {$[26$,} \\
\hline $\begin{array}{c}-4,77 \% \\
(0,1764) \\
\end{array}$ & $\begin{array}{c}-5,53 \% \\
(0,0932) \\
\end{array}$ & $\begin{array}{c}-4,95 \% \\
(0,1046) \\
\end{array}$ & \begin{tabular}{|c|}
$-6,10 \%$ \\
$(0,1130)$ \\
\end{tabular} & $\begin{array}{c}-9,13 \% \\
(0,0057) \\
\end{array}$ & $\begin{array}{c}-6,11 \% \\
(0,1262) \\
\end{array}$ & $\begin{array}{c}7,05 \% \\
(0,0266) \\
\end{array}$ & \begin{tabular}{|c|}
$-0,10 \%$ \\
$(0,9661)$ \\
\end{tabular} & $\begin{array}{c}4,35 \% \\
(0,1827) \\
\end{array}$ & $\begin{array}{c}5,37 \% \\
(0,0708) \\
\end{array}$ & $\begin{array}{c}1,34 \% \\
(0,6206) \\
\end{array}$ & $\begin{array}{c}3,91 \% \\
(0,2799) \\
\end{array}$ \\
\hline $\begin{array}{c}1,56 \% \\
(0,6900) \\
\end{array}$ & $\begin{array}{c}1,60 \% \\
(0,6649) \\
\end{array}$ & $\begin{array}{c}0,59 \% \\
(0,8641)\end{array}$ & $\begin{array}{c}4,23 \% \\
(0,3183) \\
\end{array}$ & $\begin{array}{c}4,82 \% \\
(0,1868) \\
\end{array}$ & $\begin{array}{c}3,33 \% \\
(0,4469) \\
\end{array}$ & $\begin{array}{c}-2,94 \% \\
(0,3781) \\
\end{array}$ & $\begin{array}{c}3,31 \% \\
(0,2051) \\
\end{array}$ & $\begin{array}{c}1,40 \% \\
(0,6862) \\
\end{array}$ & $\begin{array}{c}0,16 \% \\
(0,9590)\end{array}$ & $\begin{array}{c}3,17 \% \\
(0,2881)\end{array}$ & $\begin{array}{c}0,23 \% \\
(0,9509) \\
\end{array}$ \\
\hline $\begin{array}{c}-5,59 \% \\
(0,6039)\end{array}$ & $\begin{array}{c}6,68 \% \\
(0,6088) \\
\end{array}$ & $\begin{array}{l}-14,77 \% \\
(0,0878) \\
\end{array}$ & $\begin{array}{c}-4,92 \% \\
(0,6057)\end{array}$ & $\begin{array}{c}-8,24 \% \\
(0,3470)\end{array}$ & $\begin{array}{c}-3,19 \% \\
(0,7564)\end{array}$ & $\begin{array}{c}-7,75 \% \\
(0,2662)\end{array}$ & $\begin{array}{c}-7,23 \% \\
(0,1214)\end{array}$ & $\begin{array}{c}-3,45 \% \\
(0,5082)\end{array}$ & $\begin{array}{c}-4,79 \% \\
(0,3198)\end{array}$ & $\begin{array}{c}-9,16 \% \\
(0,1475)\end{array}$ & $\begin{array}{c}4,49 \% \\
(0,4265)\end{array}$ \\
\hline
\end{tabular}

PANEL C: SMALL FIRMS

\begin{tabular}{|c|c|c|c|c|c|c|c|c|c|c|c|}
\hline \multicolumn{6}{|c|}{ UNSOPHISTICATED INVESTORS } & \multicolumn{6}{|c|}{ SOPHISTICATED INVESTORS } \\
\hline$[1,5]$ & {$[6,10]$} & {$[11,15]$} & {$[16,20]$} & {$[21,25]$} & {$[26,30]$} & {$[1,5]$} & {$[6,10]$} & {$[11,15]$} & {$[16,20]$} & {$[21,25]$} & {$[26,30]$} \\
\hline $\begin{array}{c}-8,33 \% \\
(0,0798)\end{array}$ & $\begin{array}{r}-11,40 \% \\
(0,0469) \\
\end{array}$ & $\begin{array}{c}-0,96 \% \\
(0,8835)\end{array}$ & $\begin{array}{c}-5,02 \% \\
(0,4853)\end{array}$ & $\begin{array}{l}-3,98 \% \\
(0,5526)\end{array}$ & $\begin{array}{c}-2,88 \% \\
(0,5457)\end{array}$ & $\begin{array}{c}0,96 \% \\
(0,8396) \\
\end{array}$ & $\begin{array}{c}12,59 \% \\
(0,0142)\end{array}$ & $\begin{array}{c}5,67 \% \\
(0,3085)\end{array}$ & $\begin{array}{c}7,28 \% \\
(0,1457)\end{array}$ & $\begin{array}{c}11,92 \% \\
(0,0110) \\
\end{array}$ & $\begin{array}{c}2,05 \% \\
(0,7028)\end{array}$ \\
\hline $\begin{array}{c}5,25 \% \\
(0,3505) \\
\end{array}$ & $\begin{array}{c}7,61 \% \\
(0,2381)\end{array}$ & $\begin{array}{c}-8,69 \% \\
(0,2401) \\
\end{array}$ & $\begin{array}{c}-1,01 \% \\
(0,8985)\end{array}$ & $\begin{array}{c}-1,35 \% \\
(0,8545)\end{array}$ & $\begin{array}{c}-3,41 \% \\
(0,5534)\end{array}$ & $\begin{array}{c}5,60 \% \\
(0,3060)\end{array}$ & $\begin{array}{l}-10,33 \% \\
(0,0766) \\
\end{array}$ & $\begin{array}{c}-2,19 \% \\
(0,7221)\end{array}$ & $\begin{array}{c}-1,59 \% \\
(0,7850)\end{array}$ & \begin{tabular}{|c|}
$-5,85 \%$ \\
$(0,2846)$ \\
\end{tabular} & $\begin{array}{c}-0,15 \% \\
(0,9804) \\
\end{array}$ \\
\hline $\begin{array}{c}12,25 \% \\
(0,1053) \\
\end{array}$ & $\begin{array}{c}0,55 \% \\
(0,9460) \\
\end{array}$ & $\begin{array}{c}-8,84 \% \\
(0,2973) \\
\end{array}$ & $\begin{array}{c}-7,32 \% \\
(0,4735) \\
\end{array}$ & $\begin{array}{c}-6,51 \% \\
(0,4823) \\
\end{array}$ & $\begin{array}{l}-13,32 \% \\
(0,0272) \\
\end{array}$ & \begin{tabular}{|c|}
$7,37 \%$ \\
$(0,3304)$ \\
\end{tabular} & $\begin{array}{l}-10,81 \% \\
(0,1087) \\
\end{array}$ & $\begin{array}{c}-1,78 \% \\
(0,7872) \\
\end{array}$ & $\begin{array}{c}-9,30 \% \\
(0,2218) \\
\end{array}$ & $\begin{array}{r}-11,45 \% \\
(0,0883) \\
\end{array}$ & $\begin{array}{c}-3,26 \% \\
(0,6572) \\
\end{array}$ \\
\hline
\end{tabular}

On the other hand, sophisticated investors show more rational behavior. We observe statistically significant positive trading imbalances for good surprises. Their behavior is not clear for bad surprises. These investors do not show significant trading imbalances for negative surprises in almost all intervals tested. This result supports the idea of anticipation of these investors for negative surprises. 


\section{TABLE 3}

\section{BAD EARNINGS RELEASE AND TRADING REACTION}

Once the earnings announcement has been released we check if the behavior of unsophisticated investors confirms the overreaction and the self-attribution provided in the previous literature. To evaluate this hypothesis we estimate the following models:

$$
\mathrm{TI}_{\mathrm{i}, \mathrm{KL}}^{\mathrm{t}}=\alpha_{\mathrm{N}}+\lambda_{2} \mathrm{CNS}_{\mathrm{i}}+\lambda_{4} \mathrm{UNS}_{\mathrm{i}}+\omega_{\mathrm{i}}
$$

where CNS is a dummy variable which equals 1 for confirmed negative surprises and zero otherwise and UNS is a dummy variable which equals 1 for unconfirmed negative surprises and zero otherwise.

PANEL A: ALL FIRMS

\begin{tabular}{|c|c|c|c|c|c|c|c|c|c|c|c|c|}
\hline & \multicolumn{6}{|c|}{ UNSOPHISTICATED INVESTORS } & \multicolumn{6}{|c|}{ SOPHISTICATED INVESTORS } \\
\hline & {$[1,5]$} & {$[6,10]$} & {$[11,15]$} & {$[16,20]$} & {$[21,25]$} & {$[26,30]$} & {$[1,5]$} & {$[6,10]$} & {$[11,15]$} & {$[16,20]$} & {$[21,25]$} & {$[26,30]$} \\
\hline & $\begin{array}{l}-10,94 \% \\
(0,0203)\end{array}$ & \begin{tabular}{|c|}
$-9,94 \%$ \\
$(0,0209)$
\end{tabular} & $\begin{array}{l}-16,14 \% \\
(0,0001)\end{array}$ & $\begin{array}{c}-9,53 \% \\
(0,0168)\end{array}$ & $\begin{array}{l}-10,75 \% \\
(0,0129)\end{array}$ & $\begin{array}{l}-6,24 \% \\
(0,2215)\end{array}$ & $\begin{array}{c}-4,44 \% \\
(0,3388)\end{array}$ & $\begin{array}{c}-0,58 \% \\
(0,8734)\end{array}$ & $\begin{array}{c}-0,10 \% \\
(0,9809)\end{array}$ & $\begin{array}{c}2,67 \% \\
(0,5067)\end{array}$ & $\begin{array}{c}4,65 \% \\
(0,3276)\end{array}$ & $\begin{array}{c}6,55 \% \\
(0,0717)\end{array}$ \\
\hline$v_{2}$ & $\begin{array}{c}11,61 \% \\
(0,1095) \\
\end{array}$ & $\begin{array}{c}7,75 \% \\
(0,2375) \\
\end{array}$ & $\begin{array}{c}11,44 \% \\
(0,0940) \\
\end{array}$ & $\begin{array}{c}6,06 \% \\
(0,4413) \\
\end{array}$ & $\begin{array}{c}10,05 \% \\
(0,1586) \\
\end{array}$ & $\begin{array}{c}-0,84 \% \\
(0,9055) \\
\end{array}$ & $\begin{array}{c}3,35 \% \\
(0,6145) \\
\end{array}$ & $\begin{array}{c}5,52 \% \\
(0,3182) \\
\end{array}$ & $\begin{array}{c}0,37 \% \\
(0,9481) \\
\end{array}$ & $\begin{array}{c}1,87 \% \\
(0,7545) \\
\end{array}$ & $\begin{array}{c}-3,75 \% \\
(0,5479) \\
\end{array}$ & $\begin{array}{c}-7,07 \% \\
(0,2566) \\
\end{array}$ \\
\hline$\lambda$ & $\begin{array}{c}4,73 \% \\
(0,3602) \\
\end{array}$ & $\begin{array}{c}0,76 \% \\
(0,8735) \\
\end{array}$ & $\begin{array}{c}12,82 \% \\
(0,0065)\end{array}$ & $\begin{array}{c}4,69 \% \\
(0,3065)\end{array}$ & $\begin{array}{c}6,13 \% \\
(0,2221) \\
\end{array}$ & $\begin{array}{c}0,98 \% \\
(0,8621) \\
\end{array}$ & $\begin{array}{c}4,01 \% \\
(0,4260)\end{array}$ & \begin{tabular}{|c|}
$-0,64 \%$ \\
$(0,8767)$ \\
\end{tabular} & $\begin{array}{c}3,53 \% \\
(0,4334)\end{array}$ & $\begin{array}{c}1,96 \% \\
(0,6610)\end{array}$ & $\begin{array}{c}0,31 \% \\
(0,9504)\end{array}$ & $\begin{array}{c}2,27 \% \\
(0,5830) \\
\end{array}$ \\
\hline
\end{tabular}

PANEL B: LARGE FIRMS

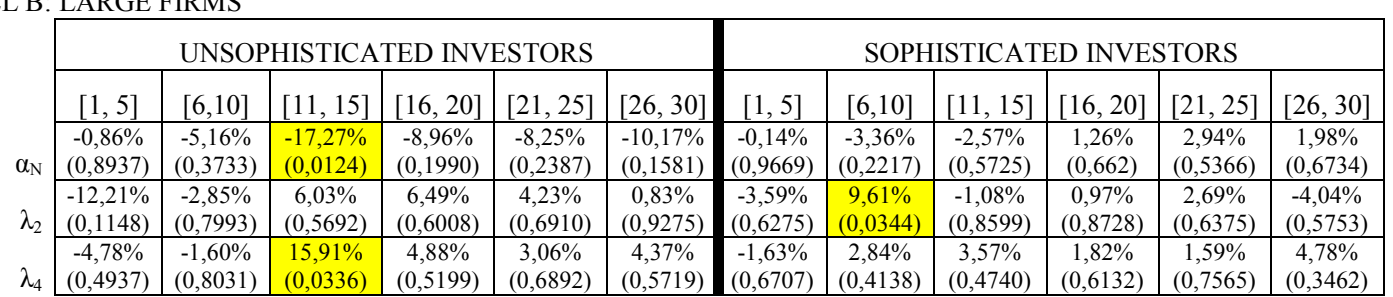

PANEL C: SMALL FIRMS

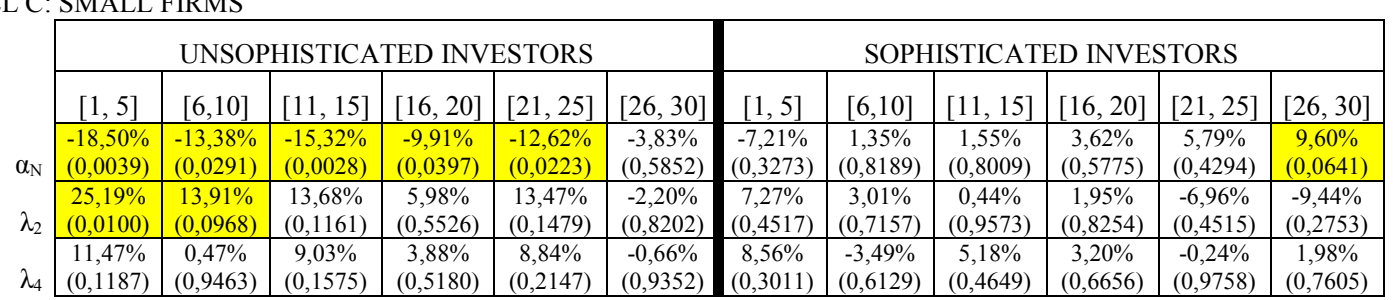

Moreover, the results allow us to conclude that for positive surprises both the unsophisticated and sophisticated investors show the overconfidence behavioral bias. In fact, we find statistically significant negative trade imbalances for unconfirmed negative surprises. This bias is not present for sophisticated investors in large firms. This result confirms the evidence found by Callen (2005).

The unsophisticated investors also show overconfidence behavior in the case of negative surprises.

The above discussion shows that sophisticated and unsophisticated investors tend to have systematically different trading behavior. 


\section{4. - ASYMMETRIC INFORMATION AROUND EARNINGS DISCLOSURE.}

An earnings disclosure reveals information unknown to most market participants, but at a predicted time. A tested result of this arrival of information is a significant effect on the firm price that gives informed agents an incentive to trade on private information prior to the announcement. ${ }^{\dagger \dagger}$ Moreover, the expectation of imminent earnings news may stimulate some traders to search for information prior to the announcement resulting in an information advantage to those agents with superior abilities to process earnings information. ${ }^{\text {t+t }}$

McNichols and Trueman (1994) and Demski and Feltman(1994) argue that information asymmetry should increase before earnings announcements, as there is a risk that trades are initiated by informed investors. Under this argument, when an earnings announcement is disclosed it should be accompanied by a decrease in the asymmetric information.

In contrast, if private information is generated by processing and interpreting a public announcement, more public information leads to more private information. Because the ability of information processors is not the same for all participants, Kim and Verrrecchia (1994) argue that the disclosure of earnings actually increases asymmetric information.

Moreover, previous empirical literature has employed firm size as a proxy for the quantity or quality both of previous information and released information. There seems to be more public information available about a big firm than a small one. Furthermore, small firms are less followed by financial analysts and there may be more uncertainty about the earnings information disclosed by small firms, thus the information content will be different. These facts can result in a different behavior of asymmetric information.

\footnotetext{
\#† See, for example, Ball y Kothari (1991), Pope and Inyangete (1992), Opong (1995), Hew et al. (1996), Elsharkawy and Garrod (1996), Kallunki (1996), Booth et al. (1997), Laurent (2000), Odabassi (1998), Landsman and Maydew (2001) and Gajewski and Quéré (2001). Arcas and Rees (1999), Fernández and García (2001) and Sanabria (2005) investigate value generation around earnings announcements in the Spanish market.

Along these lines, informed agents are also those who have searched for information prior to the anticipated announcement, resulting in an information advantage.
} 
Disclosure from a small firm is expected to have a greater impact than the disclosure from a big firm. If there is anticipation, we expect that it is greater for large firms. Atiase (1985) and (1987), Dempsey (1989), Pope and Inyangete (1992) and Yohn (1998), among others, employ firm size as a proxy for the quantity of previous information on earnings and Mohammed and Yadav (2002) use it as a proxy for the quality of the information released.

With respect to the surprise sign, the information environment of successful firms would be more stable, meaning less information asymmetry and less uncertainty than that of bad news firms (Hayn (1995) and Lang and Lundholm (1993), among others). So, in the paper we test the hypothesis that if bad news is associated with high information uncertainty environments, the information asymmetry of bad news announcements will be higher than good ones.

In this section, the probability of informed trading (PIN) model developed by Easley and O'Hara (1992) is applied to analyze the presence of asymmetric information around annual earnings disclosure. This theoretical model is used in several empirical studies (for example, Easley et al. 1996).

The PIN measure is a private information measure because it is a function of abnormal order flow. The underlying assumption is that public information is directly incorporated into prices without the need for trading activity, whereas private information is reflected in excess buying or excess selling pressure (that is, abnormal order flow).

In other words, order flow captures information which is not common knowledge because, if it were common knowledge, the specialist would have automatically moved prices to the appropriate level and there would be no trading activity.

The process of trading and learning from trading results in prices converging to full information levels.

Formally, Easley and O'Hara (1992) define the PIN

$$
\operatorname{PIN}=\frac{\widehat{\alpha} \hat{\mu}}{\widehat{\alpha} \hat{\mu}+2 \widehat{\varepsilon}}
$$


where $\alpha$ is the probability that an information event occurs, $\mu$ is the arrival rate of informed traders, $\varepsilon$ is the arrival rate of buy and sell orders of liquidity traders.

TABLE 4

\section{ASYMMETRIC INFORMATION AROUND EARNINGS DISCLOSURE}

We estimate the PIN for 30 trading days and we test if there have been changes in this measure before and after the earnings release.

$$
\operatorname{PIN}=\frac{\widehat{\alpha} \hat{\mu}}{\widehat{\alpha} \hat{\mu}+2 \hat{\varepsilon}}
$$

where $\alpha$ is the probability that an information event occurs, $\mu$ is the arrival rate of informed traders, $\varepsilon$ is the arrival rate of buy and sell orders of liquidity traders. To take into the analysis the earnings surprise sign and the firm size, we repeat the test for separated samples.

The table summarizes the parameter estimate for the PIN and p-value in parenthesis.

\begin{tabular}{|c|c|c|c|}
\hline & PRE-ANN. & POST-ANN. & Test PRE-POST \\
\hline All firms & $\begin{array}{c}17,16 \% \\
(0,0000)\end{array}$ & $\begin{array}{c}16,53 \% \\
(0,0000)\end{array}$ & $\begin{array}{c}0,63 \% \\
(0,1706)\end{array}$ \\
\hline Big firms (BF) & $\begin{array}{l}16,32 \% \\
(0,0000)\end{array}$ & $\begin{array}{l}15,88 \% \\
(0,0000)\end{array}$ & $\begin{array}{c}0,44 \% \\
(0,4120)\end{array}$ \\
\hline Small firms (SF) & $\begin{array}{c}18,48 \% \\
(0,0000)\end{array}$ & $\begin{array}{c}17,54 \% \\
(0,0000)\end{array}$ & $\begin{array}{c}0,95 \% \\
(0,2600)\end{array}$ \\
\hline Test BF-SF & $\begin{array}{c}-2,16 \% \\
(0,0006)\end{array}$ & $\begin{array}{c}-1,65 \% \\
(0,0199)\end{array}$ & \\
\hline
\end{tabular}

\begin{tabular}{|c|c|c|c|}
\hline & $17,23 \%$ & $16,27 \%$ & $0,96 \%$ \\
Good News $(\mathrm{GN})$ & $(0,0000)$ & $(0,0000)$ & $(0,0821)$ \\
\hline & $17,04 \%$ & $17,06 \%$ & $-0,02 \%$ \\
Bad News $(\mathrm{BN})$ & $(0,0000)$ & $(0,0000)$ & $(0,9778)$ \\
\hline & $0,19 \%$ & $-0,79$ & \\
Test GN-BN & $(0,7753)$ & $(0,2855)$ & \multicolumn{1}{|c}{} \\
\cline { 1 - 3 } &
\end{tabular}

\begin{tabular}{|c|c|c|c|}
\hline $\begin{array}{c}\text { Sequence } \\
(\mathrm{Se})\end{array}$ & $\begin{array}{c}17,11 \% \\
(0,0000)\end{array}$ & $\begin{array}{c}16,40 \% \\
(0,0000)\end{array}$ & $\begin{array}{c}0,72 \% \\
(0,1483)\end{array}$ \\
\hline No sequence & $17,38 \%$ & $17,06 \%$ & $0,32 \%$ \\
$(\mathrm{NSe})$ & $(0,0000)$ & $(0,0000)$ & $(0,7926)$ \\
\hline & $-0,27 \%$ & $-0,66 \%$ & \multicolumn{1}{|c}{} \\
Test Se-NSe & $(0,7280)$ & $(0,4487)$ &
\end{tabular}

Following Nyholm (2005), we estimate the PIN for 30 trading days and we test if there have been changes in this measure before and after the earnings release. To take into the analysis the earnings surprise sign and the firm size, we repeat the test for separated samples. The results are shown in Table 4.

Theory suggests that earnings news can either increase or decrease the level of information asymmetry between investors. We examine the impact of earnings announcements on information asymmetry. We can see in Table 4 that the market valuates the trade on private information in all cases where the PIN (probability of informed trade) is substantial (about 0.16 or larger) and highly statistically significant.

We also examine some firm and announcement level characteristics that may be related to the private information. The coefficients between the PIN and the quality of 
the information -measured by the firm size, which has been used as a proxy to generate information- show that big firms have a smaller the PIN and the difference is statistically significant. This result indicates a negative association between disclosure quality and information asymmetry since in large firms there is more information than in small ones.

When we analyze the information asymmetry component and take into consideration the sign of the news, we observe an interesting result. The results for good news firm indicate that the PIN after the announcement is lower than its results in preannouncement. Information asymmetry increases in the pre-announcement period and the PIN is reduced substantially in the post-announcement period. This result is interesting because in the pre-announcement period (see Table order imbalance) sophisticated investors increased their buying activity for this earnings news. On the other hand, poor earnings do not change information asymmetry, suggesting that poor earnings offer an advantage of greater information to informed traders.

The coefficients between the PIN and the earning sequence do not show statistically significant differences. This result does not support the idea that the sign of previous announcements offers an advantage of greater information to informed traders.

\section{5. - DETERMINANTS OF PRICE IMPACT}

In this section, we study the price impact determinants based on the abnormal return on the announcement day.

We test if the price impact depends on the previous sequence of the earnings. Based on an overreaction and self-attribution hypothesis, we expect a greater (smaller) reaction when the sequence is confirmed (unconfirmed). The model suggested is the following:

$$
\begin{gathered}
\mathrm{AR}_{\mathrm{i}}^{\mathrm{t}}=\alpha_{\mathrm{P}}+\beta_{1} \mathrm{CPS}_{\mathrm{i}}+\beta_{2} \mathrm{UPS}_{\mathrm{i}}+\mu_{\mathrm{i}} \\
\mathrm{AR}_{\mathrm{i}}^{\mathrm{t}}=\propto_{\mathrm{N}}+\lambda_{2} \mathrm{CNS}_{\mathrm{i}}+\lambda_{4} \mathrm{UNS}_{\mathrm{i}}+\omega_{\mathrm{i}}
\end{gathered}
$$

where $\mathrm{AR}_{\mathrm{i}}^{\mathrm{t}}$ captures the market reaction the day of the earnings announcement for the year $\mathrm{t}$. 
We also test whether the price impact depends not only on the sign of the surprise, but also on the variation of the EPS. For this question, we propose the following model:

$$
\mathrm{AR}_{i}^{t}=\beta_{1} \mathrm{PS}+\beta_{2} \mathrm{NS}+\beta_{3} \mathrm{PS}^{*} \mathrm{Abs}\left(\mathrm{EPS}_{\mathrm{i}}^{\mathrm{t}}-\mathrm{EPS}_{\mathrm{i}}^{\mathrm{t}-1}\right)+\beta_{4} \mathrm{NS}^{*} \mathrm{Abs}\left(\mathrm{EPS}_{\mathrm{i}}^{\mathrm{t}}-\mathrm{EPS}_{\mathrm{i}}^{\mathrm{t}-1}\right)
$$

where PS and NS are two dummy variables which equal 1 if the earning is a positive or negative surprise, respectively, and zero otherwise. $\operatorname{Abs}\left(\operatorname{EPS}^{\mathrm{t}}{ }_{\mathrm{i}}-\mathrm{EPS}^{\mathrm{t}-1}{ }_{\mathrm{i}}\right)$ is the absolute value of variation of the earnings per share. For these models we separate the results by firm size.

Finally, we examine whether previous information asymmetries measured by the PIN is a determinant of abnormal returns, with the following models. Relying on the findings for the PIN in the previous analysis, we control for firm size and for the surprise sign.

$$
\begin{aligned}
& \mathrm{AR}_{\mathrm{i}}^{\mathrm{t}}=\alpha+\beta_{1} \mathrm{PIN}_{\mathrm{PRE}}^{\mathrm{t}} * \mathrm{PS}+\beta_{2} \mathrm{PIN}_{\mathrm{PRE}}^{\mathrm{t}} * \mathrm{NS} \\
& \mathrm{AR}_{\mathrm{i}}^{\mathrm{t}}=\alpha+\beta_{1} \mathrm{PIN}_{\mathrm{PRE}}^{\mathrm{t}}{ }^{*} \mathrm{BIG}+\beta_{2} \mathrm{PIN}_{\mathrm{PRE}}^{\mathrm{t}}{ }^{*} \mathrm{SMALL} \\
& \mathrm{AR}_{\mathrm{i}}^{\mathrm{t}}=\alpha+\beta_{1} \mathrm{PIN}_{\mathrm{PRE}}^{\mathrm{t}} * \mathrm{BIG} * \mathrm{PS}+\beta_{2} \mathrm{PIN}_{\mathrm{PRE}}^{\mathrm{t}} * \mathrm{SMALL} * \mathrm{PS}+\beta_{3} \mathrm{PIN}_{\mathrm{PRE}}^{\mathrm{t}} * \mathrm{BIG}^{*} \mathrm{NS}+\beta_{4} \mathrm{PIN}_{\mathrm{PRE}}^{\mathrm{t}}{ }^{*} \mathrm{SMALL}{ }^{*} \mathrm{NS}
\end{aligned}
$$

where PIN ${ }^{t}$ PRE captures the probability of information asymmetry in every preannouncement period. BIG and SMALL are two dummy variables which equal 1 if the earnings announcement is for a big firm or small firm, respectively, and zero otherwise.

The results shown in Table 5, Panel A support neither the overreaction nor the self-attribution hypothesis. Even though the imbalance trading analysis showed heuristic behavioral for unsophisticated investors for positives sequences, the impact on price is not significant. The results show that the market needs more information than just the past earnings announcements or, in other words, past earnings announcements do not have the power to predict market reaction. 


\section{TABLE 5}

\section{DETERMINANTS OF PRICE IMPACT}

PANEL A.

The table reports the coefficient estimates and statistical signification between brackets for the following regression equation:

$$
\begin{gathered}
\mathrm{AR}_{\mathrm{i}}^{\mathrm{t}}=\alpha_{\mathrm{P}}+\beta_{1} \mathrm{CPS}_{\mathrm{i}}+\beta_{2} \mathrm{UPS}_{\mathrm{i}}+\mu_{\mathrm{i}} \\
\mathrm{AR}_{\mathrm{i}}^{\mathrm{t}}=\propto_{N}+\lambda_{2} \mathrm{CNS}_{\mathrm{i}}+\lambda_{4} \mathrm{UNS}_{\mathrm{i}}+\omega_{\mathrm{i}}
\end{gathered}
$$

where $\mathrm{AR}_{\mathrm{it}}$ captures the market reaction of the announcement and is the abnormal return when the (i) firm releases the annual (t) earning announcement. GF and BF are two dummies variables that take the value 1 if the market has a good or bad forecast,

\begin{tabular}{|c|c|c|c|c|c|c|c|}
\hline & \multicolumn{3}{|c|}{ Good news } & \multicolumn{3}{|c|}{ Bad news } & \\
\hline & All firms & Big firms & Small firms & All firms & Big firms & Small firms & \\
\hline & $\mathrm{AR}_{1}$ & $\mathrm{AR}_{1}$ & $\mathrm{AR}_{1}$ & $\mathrm{AR}_{1}$ & $\mathrm{AR}_{1}$ & $\mathrm{AR}_{1}$ & \\
\hline$\alpha_{P}$ & $\begin{array}{c}0,002743 \\
(0,3117)\end{array}$ & $\begin{array}{c}0,004402 \\
(0,0767)\end{array}$ & $\begin{array}{c}0,00028 \\
(0,9605)\end{array}$ & $\begin{array}{c}-0,005238 \\
(0,1616)\end{array}$ & $\begin{array}{c}0,002851 \\
(0,6574)\end{array}$ & $\begin{array}{c}-0,010499 \\
(0,0173)\end{array}$ & $\alpha_{N}$ \\
\hline$\beta_{1}$ & $\begin{array}{c}-0,002523 \\
(0,4152)\end{array}$ & $\begin{array}{c}-0,003196 \\
(0,2918)\end{array}$ & $\begin{array}{c}-0,002567 \\
(0,6907)\end{array}$ & $\begin{array}{c}0,001458 \\
(0,8195)\end{array}$ & $\begin{array}{c}-0,006496 \\
(0,6419)\end{array}$ & $\begin{array}{c}0,006599 \\
(0,3305)\end{array}$ & $\beta_{1}$ \\
\hline$\beta_{2}$ & $\begin{array}{c}-0,007774 \\
(0,1753)\end{array}$ & $\begin{array}{c}-0,009069 \\
(0,1591)\end{array}$ & $\begin{array}{c}-0,005493 \\
(0,5429)\end{array}$ & $\begin{array}{c}0,002069 \\
(0,6274)\end{array}$ & $\begin{array}{c}-0,006330 \\
(0,3661)\end{array}$ & $\begin{array}{c}0,007683 \\
(0,1533)\end{array}$ & $\beta_{2}$ \\
\hline
\end{tabular}
respectively. The table summarizes the parameter estimates and p-value in parenthesis.

PANEL B.

This table reports the coefficients estimates and statistical signification between brackets for the following regression equation:

$$
\mathrm{AR}_{\mathrm{i}}^{\mathrm{t}}=\beta_{1} \mathrm{GOOD}+\beta_{2} \mathrm{BAD}+\beta_{3} \mathrm{GOOD} * \mathrm{ABS}\left(\mathrm{EPS}_{\mathrm{it}}\right)+\beta_{4} \mathrm{BAD}^{*} \mathrm{ABS}\left(\mathrm{EPS}_{\mathrm{it}}\right)
$$

where $A_{i}$ captures the market reaction of the announcement and is the abnormal return when the (i) firm releases the annual (t) earning announcement. Good and Bad are two dummy variables that take the value of 1 if the earning is good news or bad news, respectively and $\mathrm{ABS}\left(\mathrm{EPS}_{\mathrm{it}}\right)$ is the absolute value of earning per share.

The table summarizes the parameter estimates and p-value in parenthesis.

\begin{tabular}{|c|c|c|c|}
\cline { 2 - 4 } \multicolumn{1}{c|}{} & All firms & Big firms & Small firms \\
\cline { 2 - 4 } \multicolumn{1}{c|}{} & $\mathrm{AR}_{1}$ & $\mathrm{AR}_{1}$ & $\mathrm{AR}_{1}$ \\
\hline$\beta_{1}$ & $-0,001815$ & $-0,000647$ & $-0,004052$ \\
& $(0,1959)$ & $(0,6633)$ & $(0,1164)$ \\
\hline$\beta_{2}$ & $-0,003278$ & $-0,001657$ & $-0,005329$ \\
& $(0,0615)$ & $(0,5048)$ & $(0,0336)$ \\
\hline$\beta_{3}$ & 0,002454 & 0,003215 & 0,001578 \\
& $(0,0204)$ & $(0,0093)$ & $(0,0036)$ \\
\hline$\beta_{4}$ & $-0,000190$ & $-0,000465$ & $8,99 \mathrm{E}-05$ \\
& $(0,2726)$ & $(0,0082)$ & $(0,6746)$ \\
\hline
\end{tabular}

PANEL C.

This table reports the coefficients estimates and statistical signification for the following regression equation:

$$
\begin{aligned}
& \mathrm{AR}_{\mathrm{i}}^{\mathrm{t}}=\alpha+\beta_{1} \mathrm{PIN}_{\mathrm{PRE}}{ }^{*} \mathrm{GOOD}+\beta_{2} \mathrm{PIN}_{\mathrm{PRE}}{ }^{*} \mathrm{BAD}(\mathrm{C} .1) \\
& \left.\mathrm{AR}_{\mathrm{i}}^{\mathrm{t}}=\alpha+\beta_{1} \mathrm{PIN}_{\mathrm{PRE}}{ }^{*} \mathrm{BIG}+\beta_{2} \mathrm{PIN}_{\mathrm{PRE}}{ }^{*} \mathrm{SMALL} \text { (C. } 2\right)
\end{aligned}
$$

$\mathrm{AR}_{\mathrm{i}}^{\mathrm{t}}=\alpha+\beta_{1}\left(\mathrm{PIN}_{\mathrm{PRE}}{ }^{*} \mathrm{BIG} * \mathrm{GOOD}\right)+\beta_{2}\left(\mathrm{PIN}_{\mathrm{PRE}}{ }^{*} \mathrm{SMALL}{ }^{*} \mathrm{GOOD}\right)+\beta_{3}\left(\mathrm{PIN}_{\mathrm{PRE}}{ }^{*} \mathrm{BIG} * \mathrm{BAD}\right)+\beta_{4}\left(\mathrm{PIN}_{\mathrm{PRE}}{ }^{*} \mathrm{SMALL}^{*} \mathrm{BAD}\right)(\mathrm{C} .3)$

\begin{tabular}{|c|c|c|c|c|c|}
\hline & \multicolumn{3}{|c|}{ (C.1) } & \multirow[b]{2}{*}{ (C.2) } & \multirow[b]{2}{*}{ (C.3) } \\
\hline & $\begin{array}{l}\text { All } \\
\text { Firms }\end{array}$ & $\begin{array}{c}\text { Big } \\
\text { firms }\end{array}$ & $\begin{array}{l}\text { Small } \\
\text { firms }\end{array}$ & & \\
\hline & $\mathrm{AR}_{1}$ & $\mathrm{AR}_{1}$ & $\mathrm{AR}_{1}$ & $\mathrm{AR}_{1}$ & $\mathrm{AR}_{1}$ \\
\hline$\alpha$ & $\begin{array}{l}-0,00331 \\
(0,1965)\end{array}$ & $\begin{array}{l}-0,00136 \\
(0,6713)\end{array}$ & $\begin{array}{l}-0,00759 \\
(0,0754)\end{array}$ & $\begin{array}{c}-0,00372 \\
(0,1454)\end{array}$ & $\begin{array}{l}-0,00373 \\
(0,1458)\end{array}$ \\
\hline$\beta_{1}$ & $\begin{array}{l}0,02048 \\
(0,1527)\end{array}$ & $\begin{array}{l}0,01657 \\
(0,3476)\end{array}$ & $\begin{array}{l}0,03076 \\
(0,1949)\end{array}$ & $\begin{array}{l}0,02325 \\
(0,0966)\end{array}$ & $\begin{array}{c}0,02863 \\
(0,0451)\end{array}$ \\
\hline$\beta_{2}$ & $\begin{array}{r}-0,00213 \\
(0,8822)\end{array}$ & $\begin{array}{c}-0,0043 \\
(0,8225)\end{array}$ & $\begin{array}{l}0,01113 \\
(0,6143)\end{array}$ & $\begin{array}{l}0,00499 \\
(0,7334)\end{array}$ & $\begin{array}{c}0,01307 \\
(0,4557)\end{array}$ \\
\hline$\beta_{3}$ & & & & & $\begin{array}{c}0,00792 \\
(0,6416)\end{array}$ \\
\hline$\beta_{4}$ & & & & & $\begin{array}{r}-0,00614 \\
(0,7070)\end{array}$ \\
\hline
\end{tabular}

where $A_{i}^{t}$ captures the market reaction of the announcement and is the abnormal return when the (i) firm releases the annual (t) earning announcement PINPRE captures the probability of information asymmetry in the pre-announcement period. Good and Bad are two dummy variables that take the value of 1 if the earning is good news or bad news, respectively. The table summarizes the parameter estimates and p-value in parenthesis.

On the other hand, the response of asset prices has a different sign for positive and negative surprises (Table 5, Panel B). As we expect, the relation is positive for good news (positive surprise) and negative for bad news (negative surprise). Moreover, our 
results show some differences between big and small firms and good or bad surprises, that is to say, with respect to the monetary amount in the case of a positive surprise, the market only values the magnitude of the surprise for all firms. This idea is repeated for big companies with bad surprises. For small firms the investors react knowing only the sign of the news.

In Panel $\mathrm{C}$ we investigate the relation between the probability of informed trading before the earnings announcement and the market reaction, approached through the abnormal return with the disclosure of this information. In general, the results show that the previous probability of informed trading does not have explanatory power for the impact on prices. We only found a positive and significant coefficient for big firms and positive surprise would suggest a contrary relation to expect.

\section{6. - CONCLUSIONS}

We find an important difference between sophisticated and unsophisticated investors before the earnings announcement. The results support the heuristic behavior of unsophisticated investors in that they are unable to predict the sign of the news. On the contrary, sophisticated investors have the capacity to predict the sign of the earnings release.

The evidence suggests that unsophisticated investors have less ability and resources of information than sophisticated investors or that sophisticated investors have private information. While unsophisticated investors act based on the historical sequence of earnings, sophisticated investors have the capacity to predict the sign of the earnings release.

In general, the results in the post-announcement period allow us to conclude the overconfidence behavioral bias for both investors. However, this bias is not present for sophisticated investors in big firms.

With respect to the probability of informed trading, we can confirm that the market valuates the trade based on private information. Additionally, the results show that big firms, with more public information, have a smaller PIN than small companies. 
This result indicates a negative association between quantity and quality of the disclosure and information asymmetry.

Furthermore, the result obtained for the PIN before the positive surprises reinforces the idea that sophisticated investors have private information. In this period and for these kinds of announcements, the sophisticated investors show buy trades imbalances.

The evolution of prices does not show a relationship with the trade imbalance. However, the trade imbalance analysis shows heuristic behavior by unsophisticated investors for positives earnings sequences. The results support neither the overreaction hypothesis nor the self-attribution hypothesis.

The response in asset prices depends on the sign of the surprise. As expected, the relation is positive (negative) for positive (negative) earnings surprises.

In general, the results show that the previous probability of informed trading does not have explanatory power for the impact on prices. We only found a positive and significant coefficient for big firms and positive surprise would suggest a contrary relation to expect.

\section{REFERENCES}

Abad, D., S. Sanabria and J. Yagüe (2009) "Strategic timing of annual earnings announcements: evidence from an order-driven market" Review of Quantitative Finance and Accounting 32, 287-308.

Acker, D., M. Stalker e I. Tonks (2002) "Daily closing inside spreads and trading volumes around earnings announcements" Journal of Business Finance and Accounting 29, 1149-1179.

Affleck-Graves, J., C.M. Callahan, y N. Chipalkatti (2002) "Earnings predictability, information asymmetry, and market liquidity" Journal of Accounting Research 40, 561-583.

Arcas, M.J. y W.P. Rees (1999) "Regularities in the equity price response to earnings announcements in Spain” European Accounting Review 8, 585-607. 
Atiase, R.K. (1985) "Predisclosure information, firm capitalization and security price behaviour around earnings announcements" Journal of Accounting Research 23, 21-36.

Ball, R. y S.P. Kothari (1991) "Security returns around earnings announcements" Accounting Review 66, 718-738.

Barberis, N., A. Shleifer y R. Vishny (1998) "A model of investor sentiment" Journal of Financial Economics 49, 307-343.

Booth, G.G., J. Kallunki y T. Martikainen (1997) "Delayed price response to the announcements of earnings and its components in Finland" European Accounting Review 6, 377-392.

Brooks, R.M. (1994) "Bid-ask spread components around anticipated announcements" Journal of Financial Research 27, 375-386

Callen, J.L., Hope, O.K. and Segal, D. (2005) "Domestic and foreign earnings, stock return variability and the impact of investor sophistication" Journal of Accounting Research, 43, 377-412

Chen, L.K.C. y J. Lakonishok (1991) "Institutional trades and intra-day stock price behaviour" Working paper University of Illionois.

Daniel, K., D. Hirshleifer y A. Subrahmanyam (1998) "Investor psychology and security market under and overreactions", Journal of Finance 53, 1839-1885.

Dempsey, S.J. (1989) "Predisclosure information search incentives, analyst following and earnings announcement price response" Accounting Review 64, 748-757

Diamond, D.W. y Verrecchia, R. (1987) "Constraints on short-selling and asset price adjustment to private information" Journal of Financial Economics 18, 277-311.

Easley, D. y M. O'Hara (1992) "Time and the process of security price adjustment" Journal of Finance 47, 577-605.

Fama, E.F. y K.R. French (1992) "The cross-section of expected stock returns" Journal of Finance 47, 427-465.

Fama, E.F. y K.R. French (1993) "Common risk factors in the returns on stocks and bonds" Journal of Financial Economics 33, 3-56. 
Fernández, E. y M. García (2001) "Los efectos lunes y tamaño: Una justificación basada en las asimetrías de información" Análisis Financiero 85, 30-50.

Frieder, L. (2004) "Earnings announcements, order flow and returns" Working Paper, Krannert School of Management, Purdue University.

Gajewski, J. y B.P. Quéré (2001) "The information content of earnings and turnover announcements in France” European Accounting Review 10, 679-704.

Gajewski, J.F. (1999):’Earnings announcements, asymmetric information, trades and quotes" European Financial Management 5, 411-423.

Hayn, C. (1995) "The information content of losses" Journal of Accounting and Economics 20, 125-153.

Hew, D., L. Skerratt, N. Strong y M. Walker (1996) "Post earnings announcement drift: some preliminary evidence for the UK" Accounting and Business Research 26, 283-293.

Kim, O y R. Verrecchia (1994) "Market liquidity and volume around earnings announcements" Journal of Accounting and Economics 17, 41-67.

Krinsky, I. y Lee, J. (1996) "Earnings announcements and the components of the bid-ask spread" Journal of Business 51, 1523- 1535.

Krishnan, M. y U. Battacharya (1989) "To believe or not to believe" Working Paper, Purdue University.

Landsman, W.R., y E.L. Maydew (2001) "Beaver (1968) revisited: has the information content of quarterly earnings announcements declined in the past three decades?" Journal of Accounting Research 40, 797-808.

Laurent, M. (2000) "The effect of earnings release for Belgian listed companies" Working Paper WP-CEB: nº 03/005, Université Libre de Bruxelles.

Lee, C.M.C., Mucklow, B. y Ready, M.J. (1993) "Spreads, depths, and the impact of earnings information an intraday analysis" Review of Financial Studies 6, 345-374.

Lee, M.C.M. (1992) "Earnings news and small traders. An intraday analysis" Journal of Accounting and Economics 15, 265-302. 
Lipe, R., L. Bryant y S. Widener (1998) "Do nonlinearity, firm-specific coefficients, and losses represent distinct factors in the relation between stock returns and accounting earnings?" Journal of Accounting and Economics 25, 195-214.

Mohammed, S. y P. Yadav (2002) "Quality of information and volatility around earnings announcements" European Finance Association Annual Conference WP.

Nyholm, K, (2002) "Estimating the Probability of Informed Trading" Journal of Financial Research, 25, 485-505

Odabasi, A. (1998) 'Security returns' reactions to earnings announcements: a case study on the Istanbul stock exchange" Review of Social, Economic and Administrative Studies 12, 3-19.

Opong, K.K. (1995) "The information content of interim financial reports: UK evidence" Journal of Business Finance and Accounting 22, 269-279.

Otogawa, K. (2003) "Market liquidity around quarterly earnings announcements: evidence from Japan” Working Paper, Kobe University.

Patel, S.A. (1993) "Intra-day bid-ask spread surroundings earnings announcements and information asymmetry" Dissertation in Finance, University of Pennsylvania

Pope, P. y Ch.G. Inyangete (1992) "Differential information, the variability of UK stock returns and earnings announcements" Journal of Business Finance and Accounting 19, 603-623.

Pronk, M. (2001) "The impact of intraday timing of earnings announcements on market liquidity" Working Paper, Tilburg University.

Sanabria, S. (2005) "Comportamiento de los precios y volúmenes de negociación ante anuncios de beneficios anuales" Revista de Economía Financiera 5, $32-66$.

Shanthikumar, D. (2004) "Small trader reactions to consecutive earnings surprises" Working Paper, University of Stanford.

Vega, C. (2006) "Stock price reaction to public and private information" Journal of Financial Economics 82, 103-133. 
Venkatesh, P.C. y Chiang, R. (1986) "Information asymmetry and the dealer's bid-ask spread A case study of earnings and dividend announcements" Journal of Finance 41, 1089-1102.

Vieru, M., J. Perttunen y H. Schadewitz (2006) "How investors trade around interim earnings announcements" Journal of Business Finance and Accounting 33, 145 178.

Yohn, T.L. (1998) "Information asymmetry around earnings announcements" Review of Quantitative Finance and Accounting 11, 165-182. 